\title{
Anne Mayes Receives Woody Award for 2002
}

One of the most pleasant duties of the Materials Research Society presidency is choosing the recipient of the Woody Award, an honor bestowed on one volunteer each year in recognition of outstanding service and dedication to MRS. In 2002, MRS President Alex King presented the Woody Award to Anne Mayes of the Massachusetts Institute of Technology.

The award is named for its first recipient, 1984 MRS President Woody White (Oak Ridge National Laboratory), who exemplified a devotion to excellence in all of his work as an MRS member and volunteer. In most cases, the Woody Award goes to a volunteer who has spent many years in leadership roles, persistently working for the benefit of the Society's members. In a few cases, the award goes to an individual for a single, Herculean contribution, and this is an accurate description of the Woody Award recipient for 2002

Anne Mayes joined the MRS Council in January 2000, but left the Board of Directors in December 2002, having played the leading role in converting the former into the latter as part of a strategic reorganization of the Society's governance structure. The changes that Mayes coordinated and drove to completion are having a great impact on the Society's ability to remain agile and responsive to new opportunities while keeping a clear eye on its long-term strategic goals.

King said, "These do not sound like exciting matters, perhaps, but they under-

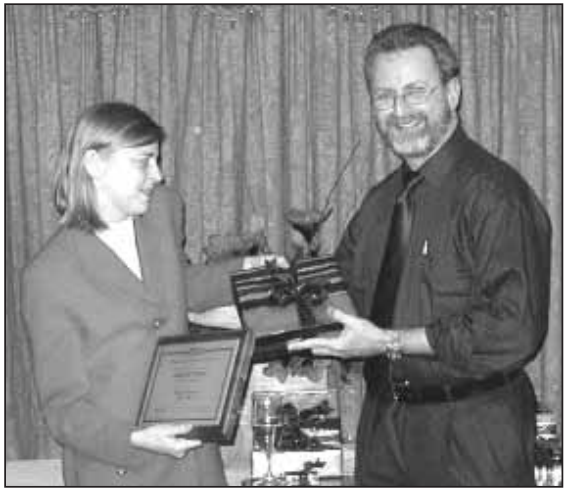

Anne Mayes (left) receives the 2002 Woody Award from MRS President Alex King.

lie a key reinvention and re-enabling of the Society, whose impact will be quite profound. At a time when everything is going 'nano,' Anne truly saved us from micromanagement."

During the transition from oversight by a council to leadership by a strategically thinking board, Mayes took on the role of chair of the task force that managed the process, and later she became the chair of the Board's planning committee, which did much of the work of ensuring that the new structure will have an empowering effect on the various standing committees of the Society. Her low-key approach concealed a great deal of challenging work and steady determi- nation throughout 2001 and 2002, during which time Mayes was also working on the establishment of another professional society and helping MRS to improve and intensify its programming in the area of biological materials. In making this award, King noted that Mayes had frequently placed the interests of MRS above her own, truly in the tradition of the namesake of the Woody Award.

Mayes worked closely with many of the MRS leaders and its staff during the transition and always made sure that the efforts of others were recognized. Amy Bosetti, formerly of MRS Headquarters, commented that "with her professionalism, eloquence, and fortitude, Anne was a key instrument in taking the MRS governing body to territory it has never gone before; a governing board with a well-defined road map enabling it to realize its tremendous leadership potential. Anne is truly one of MRS's most precious resources."

Mayes has also been recognized by MRS for her scientific achievements; she received the Outstanding Young Investigator Award in 1998 for "incisive theoretical and experimental investigations of macromolecules at and near surfaces and interfaces leading to tailorable surface properties, especially novel biocompatible substrates." The Woody Award is an expression of MRS's gratitude to Mayes for her pivotal role in reinventing the Society's governance, renewing its agility in dealing with short-term issues and refocusing leadership efforts on the future.

\section{Got materials? Have poetry on the mind? Send in a Haiku.}

Rules:

- three lines: 5-7-5 syllables (variations include syllable patterns of 3-5-3, 5-7-4, 5-12, ...)

- first two lines describe something

- third line turns it into an analogy or metaphor (or a punchline)

- if possible, one or more lines with internal alliteration

Note: In Japanese Haiku, where the poetry form originated, there is usually a reference to one of the four seasons.

Post your haiku(s) on the MRS Bulletin board in the Publications area at the 2003 Materials Research Society Fall Meeting in Boston, or e-mail submissions to bulletin@mrs.org by December 5, 2003. Provide your name, institution, and contact information-collaborations encouraged. MRS Bulletin will publish a selection of submissions.

$$
\begin{gathered}
\text { aluminum stripe - } \\
\text { voids form, drift - metal hillocks - } \\
\text { electron wind - }
\end{gathered}
$$

